\title{
Herbaceous plant community structure of ancient and recent forests in two contrasting forest types
}

\author{
Kris Verheyen*, Beatrijs Bossuyt, Olivier Honnay, M artin Hermy \\ Laboratory for Forest, $\mathrm{N}$ ature and Landscape R esearch, University of Leuven, Leuven, Belgium
}

Received N ovember 11, $2002 \cdot$ A ccepted J uly 7, 2003

\begin{abstract}
It has already been extensively documented that major floristic differences between ancient and recent temperate broad-leaved forests exist. H ence, the question raises whether the herb layer community structure and organization of ancient and recent forests also differs and whether these differences are the same in productive vs. unproductive forest types? Therefore, we selected 127 relevés situated in productive Alno-Padion forests and 69 relevés situated in less productive Quercion forests out of a larger data-set containing 640 relevés from northern Belgium. The plots differed with respect to land use history but it was assured that no covariation between land use history on the one hand, and soil texture, soil drainage and canopy composition on the other occurred. In both forest types, about $30 \%$ of the studied species exhibited an association with either ancient or recent forests. Persistent differences between ancient and recent forests in life-form spectra in general and in the number and abundance of geophytes in particular were found as well. Few changes in the community structure of productive Alno-Padion forests were observed after 70 years of recovery. O nly in the youngest Alno-Padion forests (i.e. $<70$ years) species numbers and total cover of the herb layer were lower and co-occurrence patterns did not differ from random. In general, community recovery appeared to be slower in unproductive $\mathrm{Q}$ uercion forests. Species numbers, species abundance distributions, species co-occurrence patterns and plot dissimilarity still changed after 120 years. The persistent differences in both communities can be explained by the strong dispersal limitation of many of the involved species, but in the Quercion forests recovery is probably also severely hampered by establishment limitation.

Es wurde bereits ausführlich dokumentiert, dass größere floristische Unterschiede zwischen sehr alten und jüngeren gemäßigten Laubwäldern existieren. Daher stellt sich die Frage, ob sich die Lebensgemeinschaftsstruktur und -organisation der Krautschicht ebenfalls unterscheidet und ob diese Unterschiede die gleichen bei produktiven vs. unproduktiven Waldtypen sind? Deshalb wählten wir aus einem größeren Datensatz, der 640 Aufnahmen aus dem nördlichen Belgien enthält, 127 A ufnahmen, die in produktiven Alno-Padion-Wäldern lagen, und 69 Aufnahmen, die in weniger produktiven Quercion-Wäldern lagen. Die Probeflächen unterschieden sich bezüglich der Landnutzungsgeschichte, aber es wurde sichergestellt, dass keine Kovarianz zwischen der Landnutzungsgeschichte auf der einen Seite und der Bodenstruktur, der Bodenentwässerung und der Blätterdachstruktur auf der anderen Seite bestand. In beiden Waldtypen zeigten ungefähr 30\% der untersuchten A rten eine Assoziation entweder mit sehr alten oder jüngeren Wäldern. N achhaltige Unterschiede zwischen sehr alten und jüngeren Wäldern wurden ebenfalls bei den Lebensform-
\end{abstract}

* Corresponding author: Kris Verheyen, University of Leuven, Laboratory for Forest, N ature and Landscape R esearch, Vital Decosterstraat 102, B-300 Leuven, Belgium, Phone: ++32-16-329737, Fax: ++ 32-16-329760, E-mail: kris.verheyen@agr. kuleuven.ac.be 
Spektren im Allgemeinen und bei den A nzahlen und A bundanzen der Geophyten im Besonderen gefunden. Es wurden wenige Veränderungen in der Lebensgemeinschaftsstruktur der produktiven Alno-Padion-W äldern 70 Jahre nach der Erholung beobachtet. $\mathrm{N}$ ur in den jüngsten Alno-PadionWäldern (d.h. <70 Jahre) waren die Artenzahlen und die G esamtdeckung der K rautschicht geringer und die M uster gemeinsamen Vorkommens unterschieden sich nicht von einem Z ufallsmuster. Die Erholung der Lebensgemeinschaft schien im Allgemeinen in den unproduktiven Q uercion-Wäldern langsamer zu sein. Die A rtenzahlen, die Verteilung der A rten-A bundanzen, die M uster gemeinsamen Vorkommens der Arten sowie die Probeflächendissimilarität veränderten sich noch nach 120 Jahren. Die nachhaltigen Unterschiede in den beiden G emeinschaften können durch die starke Limitierung der Ausbreitung bei vielen der beteiligten Arten erklärt werden, in den QuercionWäldern ist die Erholung durch Umw eltbegrenzungen ernsthaft behindert.

Key words: ancient forest - dispersal limitation - forest plant colonization - plant community structure - secondary forest succession

\section{Introduction}

It has been extensively documented that there are major differences between ancient and recent forests in terms of plant species composition (e.g. Peterken 1974, H ermy \& Stieperaere 1981, Dzwonko \& Loster 1990,1992 , Brunet $\&$ von O heimb 1998, Bossuyt et al. 1999a). These differences can be both quantitative (i.e. number of plant species present) and qualitative (i.e. identity of the species present), and they may be due to two types of bottlenecks during the colonization process of certain forest plant species (so called 'ancient forest plant species') (Honnay et al. 1998, Hermy et al. 1999). The first relates to limitations in propagule production and dispersal of the species. $M$ ost ancient forest species produce few seeds and/or lack efficient dispersal mechanisms (Hermy et al. 1999, Verheyen et al. 2003). Especially when recent target forests are spatially separated from the ancient source forest, colonization is hampered (Grashof-Bokdam 1997, Butaye et al. 2001). The second bottleneck relates to the establishment ability of forest plant species, i.e. the ability of seeds to germinate, establish, grow and reproduce. Due to their mainly stress tolerant plant strategy (sensu Grime 1977), a lot of ancient forest plant species lack the ability to compete successfully with more competitive species that are typical of the often nutrient enriched and relatively open canopy conditions in young forests on former agricultural land (H onnay et al. 1999, Verheyen \& H ermy 2001).

$M$ ost studies up to now dealing with differences in terms of species composition between ancient and re cent forest have concentrated on individual species, by identifying indicator species for ancient forest or by deriving species-specific colonization rates (e.g. Peterken 1974, Brunet 1993, Wulf 1997, Brunet \& von
O heimb 1998, Honnay et al. 1998, Bossuyt et al. 1999a, Dzwonko 2001). Here, we mainly focus on changes in community structure during succession towards communities comparable to those in ancient forest and explore whether community structure can as well be used as an indicator for forest age. Community structure is defined as co-occurrence and co-abundance of plant species. Because community structure partly results from plant-plant interactions and because the competitive interactions between species depend on the nutrient status of the soil, changes in community structure are expected to be different between forest types (e.g. Tilman 1987, 1988). Therefore, differences in community structure during succession between a productive and a less productive forest type were studied.

Community structure in successional forests has been studied before (e.g. Bazzaz 1975, Christensen \& Peet 1984, $\mathrm{H}$ alpern et al. 1990, Kosala \& G ross 1999), but most of these studies focused on time spans much shorter than 100 years. Because it is known now that 100 years is a relatively short time period for forests to recover (see above), it can be expected that the evolution of community structure is not at its end after this time span. M oreover, many of the documented succession series in secondary forests are only partly relevant for western Europe, and for our study region in Flanders in particular. There, tree layers are mostly planted at the time of agricultural abandonment, and in contrast to classical studies on spontaneous old-field succession (e.g. Bazzaz 1975), the gradual canopy closure and changing canopy composition are not major factors generating herb layer species turnover and successional patterns. Thus, we are in a unique situation in which we can study changes in the herb layer community without having to account for possible covarying changes in the forest canopy. 
The following specific research questions are dealt with:

- Are there still changes in the diversity and in the community structure of the herb layer after more than 100 years of secondary succession in forests planted on former agricultural land?

- Is the development of community structure during succession different between productive and unproductive forest types?

\section{Materials and methods}

\section{Study area}

All studied forests are situated in the former County of Flanders, which comprises the northwestern part of Belgium. Altitude ranges from 0 to $200 \mathrm{~m}$ above sea level and soil texture varies from sand in the northern parts to loam in the southern parts. In Belgium in general and in the County of Flanders in particular, most forests were already cleared very early, see Tack et al. (1993) and Verheyen et al. (1999) for more details. At present, forest covers less than $5 \%$ of the total area and only a small fraction of the forest cover is assumed to be 'ancient forest'. With ancient forest we do not mean unmanaged, old growth or primeval forests, but rather forest that has existed at least since a certain date and for which it is unlikely that it was ever reclaimed for agriculture before that date. In Flanders, 1775 is generally used as the pivotal date to distinguish between ancient and recent forests, since the first large-scaled (approximately 1/12,500) and area covering map was produced at that time (the De Ferraris map). M ost recent forests were either established on former heathlands in the second half of the 19th and the early 20th century or on abandoned grasslands in the river valleys after World War II.

\section{Data collection}

From 1977 to 1983, 183 deciduous forests varying in size between $<1$ ha and $>1000$ ha were sampled according to the principles of Braun-Blanquet (Westhoff $\&$ van der M aarel 1978). Herb layer species abundance (including brypophytes) in 640 relevés was estimated as percent cover per plot (decimal scale, Londo 1976). Plot size ranged from 100 to $200 \mathrm{~m}^{2}$ (usually $150 \mathrm{~m}^{2}$ ). Except a few large forests, only one or two relevés per forest were made. Plantations on grasslands were excluded, except when a well-developed shrub layer was already present. At the same time soil texture and soil drainage were recorded as nominal variables. A fterwards, the relevés were divided in two distinct historical types depending on former land use: plots from ancient forests (pre-1775; $>200$ years) and plots from recent forest (post-1775; $\leq 200$ years). The plots in recent forest were further subdivided in three classes: (1) 200-120 years, (2) 120-70 years, and (3) 70-20 years. Further details about the sampling methods and the forests studied can be found in Hermy $(1988,1992)$.

In this paper, we used the TWIN SPAN -classification (H ill 1979) of the 640 relevés in phytocoena described by Hermy (1988) and selected 127 plots situated in Alno-Padion and 69 plots situated in Quercion forest communities for further analysis. It was assured that there was no covariation between land use history on the one hand, and soil texture, soil drainage and canopy composition on the other. The productive and species-rich Alno-Padion communities were primarily found in mesic but infrequently flooded parts of lowland river valleys. Soils were relatively fine textured and mildly acidic to neutral. The tree layer in ancient and recent forests was dominated by Populus $x$ canadensis (respectively in $84 \%$ and $77 \%$ of the plots). Other frequently occurring tree species were Fraxinus excelsior and Q uercus robur. The total cover of trees and shrubs in ancient forests $(150 \%)$ was somewhat higher than in recent forests $(120 \%)$, but this difference can be reduced to the lower abundance in the recent forests of only one species, notably Corylus avellana. The less productive and species-poor Quercion communities were primarily found outside the valleys, on relatively dry, more coarse textured and mildly acidic to acidic soils. The tree layer in ancient and recent forests was dominated by Q uercus robur (respectively $91 \%$ and $85 \%$ of the plots). Betula pendula and Fagus sylvatica were the second most frequent species. The total cover of trees and shrubs was similar in the ancient and recent forests (respectively $95 \%$ and $81 \%$ ). The frequency and average cover of the most common understorey species of both communities are listed in Table 1.

\section{Data analysis}

Species composition in ancient vs. recent forest was compared in two ways: (1) By assessing the association of individual species with ancient or recent forest by means of a Pearson $\mathrm{Chi}^{2}$ test, and (2) by assessing the change in life-form spectra (adapted from Raunkiaer 1934). Therefore, the relative number and abundance of life-form classes were calculated by summing the number or cover of species of each life form and dividing that by the total number of species or cover in each plot. Differences in contribution of life-form types between age classes were tested separately for each forest type with a M ann-Whitney or KruskalWallis test (Siegel \& Castellan 1988). 
Table 1. Overall frequency $(F)$, average cover $(C)$, frequency in ancient forest $\left(F_{a}\right)$ and frequency in recent forest $\left(F_{r}\right)$ of the understory species occurring in more than $15 \%$ of the plots in either of the two forest types. Species exhibiting a significant association with ancient or recent forest are indicated (Pearson Chi ${ }^{2}$ test: $(*), 0.1>p \geq 0.05 ; *, 0.05>p \geq 0.01 ; * *, 0.01>p \geq 0.001 ; * * *, 0.001>p)$. Nomenclature follows De Langhe et al. (1983) for the vascular plants and Margadant (1973) and Mardagant \& During (1973) for the bryophytes.

\begin{tabular}{|c|c|c|c|c|c|c|c|c|c|}
\hline \multirow[b]{2}{*}{ Species } & \multicolumn{4}{|c|}{ Quercion forests } & \multirow[b]{2}{*}{ Species } & \multicolumn{4}{|c|}{ Alno-Padion forests } \\
\hline & $\begin{array}{l}F(\%) \\
n=69\end{array}$ & $\mathrm{C}(\%)$ & $\begin{array}{l}\mathrm{F}_{\mathrm{a}}(\%) \\
\mathrm{n}=43\end{array}$ & $\begin{array}{l}F_{r}(\%) \\
n=26\end{array}$ & & $\begin{array}{l}F(\%) \\
n=127\end{array}$ & $\mathrm{C}(\%)$ & $\begin{array}{l}F_{a}(\%) \\
n=63\end{array}$ & $\begin{array}{l}\mathrm{F}_{\mathrm{r}}(\%) \\
\mathrm{n}=64\end{array}$ \\
\hline Rubus fructicosus agg. & 87 & 25.3 & 88 & 85 & Rubus fructicosus agg. & 91 & 15.5 & 95 & 87 \\
\hline Mnium hornum & 72 & 1.9 & 74 & 69 & Eurhynchium praelongum & 90 & 10.1 & 90 & 90 \\
\hline Dicranella heteromalla & 67 & 1.0 & 63 & 73 & Urtica dioica & 88 & 16.4 & 86 & 90 \\
\hline Polytrichum formosum & 61 & 1.0 & 58 & 65 & Poa trivialis & 77 & 4.1 & 75 & 81 \\
\hline Teucrium scorodonia & 45 & 2.1 & 46 & 42 & Geum urbanum & 72 & 2.2 & 75 & 71 \\
\hline Hypnum cupressiforme $(*)$ & 45 & 1.0 & 37 & 58 & Filipendula ulmaria & 73 & 5.1 & 71 & 76 \\
\hline Dryopteris carthusiana & 42 & 1.4 & 44 & 38 & Ranunculus ficaria $(*)$ & 71 & 13.9 & 79 & 65 \\
\hline Molinea caerulea & 41 & 11.1 & 35 & 50 & Brachythecium rutabulum & 65 & 2.3 & 62 & 68 \\
\hline Holcus mollis** & 36 & 9.0 & 49 & 15 & Galeopsis tetrahit* & 63 & 1.3 & 54 & 71 \\
\hline Blechnum spicant & 36 & 2.8 & 37 & 35 & Moehringia trinerva & 65 & 2.2 & 59 & 71 \\
\hline Isopterygium elegans & 30 & 1 & 37 & 19 & Glechoma hederacea & 61 & 15.8 & 54 & 68 \\
\hline Carex pilulifera & 29 & 2.2 & 26 & 35 & Galium aparine & 60 & 3.2 & 59 & 60 \\
\hline Dicranum scoparium * & 28 & 1 & 19 & 42 & Adoxa moschatellina & 53 & 5.5 & 52 & 55 \\
\hline Dryopteris dilatata & 26 & 2.1 & 28 & 23 & Cirsium palustris & 53 & 1.5 & 51 & 56 \\
\hline Leucobryum glaucum* & 24 & 1.2 & 16 & 38 & Plagiothecium denticulatum & 52 & 1.3 & 54 & 51 \\
\hline Holcus lanatus $(*)$ & 23 & 2.4 & 30 & 12 & Primula elatior $* * *$ & 50 & 4.5 & 67 & 35 \\
\hline Maianthemum bifolium* & 22 & 14.3 & 30 & 8 & Rumex sanguineus & 49 & 1.7 & 44 & 54 \\
\hline Polygonatum multiflorum ** & 20 & 3.1 & 30 & 4 & Anemone nemorosa $* * *$ & 48 & 17.7 & 67 & 30 \\
\hline Atrichum undulatum & 20 & 1 & 21 & 19 & Cardamine pratensis & 48 & 1.9 & 49 & 48 \\
\hline Pteridium aquilinum $* *$ & 19 & 19.1 & 26 & 0 & Polygonatum multiflorum * & 43 & 2.1 & 54 & 33 \\
\hline Lonicera periclymenum $(*)$ & 19 & 3.7 & 26 & 8 & Angelica sylvestris & 46 & 1.2 & 41 & 52 \\
\hline Agrostis vinealis & 16 & 2.5 & 16 & 15 & Atrichum undulatum & 40 & 1.5 & 41 & 40 \\
\hline Quercus robur & 16 & 1.4 & 21 & 8 & Valeriana officinalis & 40 & 2.0 & 43 & 38 \\
\hline Pohlia nutans & 16 & 1 & 12 & 23 & Stachys sylvatica & 40 & 1.9 & 37 & 44 \\
\hline \multirow[t]{28}{*}{ Athyrium filix-femina } & 16 & 1.5 & 16 & 15 & Deschampsia cespitosa * & 36 & 7.6 & 48 & 25 \\
\hline & & & & & Mnium hornum & 36 & 1.4 & 41 & 32 \\
\hline & & & & & Lamium galeobdolon $* * *$ & 33 & 26.7 & 52 & 14 \\
\hline & & & & & Ribes rubrum* & 32 & 4.6 & 24 & 41 \\
\hline & & & & & Circaea lutetiana & 31 & 7.9 & 32 & 31 \\
\hline & & & & & Holcus lanatus & 31 & 2.9 & 25 & 38 \\
\hline & & & & & Ajuga reptans & 31 & 2.4 & 27 & 37 \\
\hline & & & & & Carex remota & 29 & 3.2 & 30 & 29 \\
\hline & & & & & Viola riviniana & 28 & 1.4 & 25 & 30 \\
\hline & & & & & Fraxinus excelsior & 24 & 3.5 & 27 & 21 \\
\hline & & & & & Lonicera periclymenum & 24 & 1.2 & 29 & 19 \\
\hline & & & & & Galium palustre & 23 & 1.2 & 25 & 21 \\
\hline & & & & & Lophocolea bidentata $(*)$ & 22 & 1.1 & 16 & 29 \\
\hline & & & & & Sambucus nigra & 22 & 1.0 & 17 & 27 \\
\hline & & & & & Humulus lupulus & 20 & 1.8 & 16 & 22 \\
\hline & & & & & Carex sylvatica & 20 & 1.1 & 24 & 16 \\
\hline & & & & & Scrophularia nodosa $* *$ & 20 & 1.0 & 10 & 32 \\
\hline & & & & & Hedera helix & 19 & 16.2 & 22 & 6 \\
\hline & & & & & Fissidens taxifolius & 19 & 1.2 & 19 & 19 \\
\hline & & & & & Dryopteris dilatata $(*)$ & 17 & 3.9 & 22 & 11 \\
\hline & & & & & Rubus caesius & 17 & 3.8 & 19 & 14 \\
\hline & & & & & Ranunculus repens & 17 & 2.5 & 13 & 22 \\
\hline & & & & & Paris quadrifolia ** & 17 & 1.9 & 29 & 6 \\
\hline & & & & & Lysimachia nummularia $(*)$ & 17 & 1.7 & 11 & 24 \\
\hline & & & & & Quercus robur & 17 & 1.1 & 14 & 21 \\
\hline & & & & & Iris pseudacorus & 17 & 1.0 & 14 & 19 \\
\hline & & & & & Athyrium filix-femina & 17 & 1.0 & 22 & 13 \\
\hline & & & & & Arum maculatum * & 15 & 1.8 & 22 & 8 \\
\hline
\end{tabular}


Changes in community structure during forest succession were assessed using three complementary approaches:

(1) First, the total cover as the sum of the individual species' cover, the number of species (alpha diversity), Shannon-Wiener diversity and equitability (see M agurran 1988) of each plot was calculated and differences between forest age classes were tested for each forest type separately with a Mann-Whitney or K ruskal-Wallis test. Changes in species abundance distributions over the age classes were also assessed using rank abundance curves. These curves were constructed by ranking the log of the species cover values in the plots from highest to lowest. $\mathrm{N}$ ext, the fit to the four most common rank abundance models (geometric, log series, log normal and broken stick; Begon et al. 1996) was assessed for each plot by means of a $\mathrm{Chi}^{2}$ test implemented in the software package Species Diversity \& Richness 3.0 (Pisces Conservation Ltd 2002). This allowed us to determine the frequencies of the best fitting models in the respective age classes.

(2) N ext, we tested whether understorey communities become more structured as succession proceeds. Therefore, species co-occurrence patterns in the different age classes were quantified by means of the C-score of Stone \& Roberts (1990). If this index is unusually large compared with a null distribution, there is less pairwise species co-occurrence (i.e. segregation) than expected by chance. If the index is unusually small, there is more species co-occurrence (i.e. aggregation) than expected (cf. Sanders et al. 2003). Ecosim 7.0 (Gotelli \& Entsminger 2002) was used to construct a null distribution and $p$-value for the observed C-score. Following Gotelli \& M cCabe (2002), we opted to retain the row and column totals in the matrices, so that each random matrix had the same number of species per site and the same number of sites per species as did the real matrix. For each test, 5000 random C-scores were created and compared with the observed score. To be able to compare the results across different age classes and forest types, the Standardized Effect Size (SES) was used. The SES is calculated as follows: $\mathrm{SES}=\left(\mathrm{l}_{\text {obs }}-I_{\mathrm{sim}}\right) / \sigma_{\text {sim }}$ in which lobs is the observed index and Isim and osim are respectively the mean and the standard deviation of the 5000 simulated indices (more details can be found in Gotelli \& Entsminger 2002).

(3) Finally, we examined for divergence or convergence of the successional pathway, by comparing the mean dissimilarity between the plots of each age class. Dissimilarity was determined by calculating the average Euclidean distance based on species cover values between each pair of plots in every age class. Differences between age classes were tested with a $M$ onte Carlo ANOVA using Ecosim 7.0 (Gotelli \&
Entsminger 2002). M onte Carlo analysis is necessary here since the $\left(n^{2}-n\right) / 2$ generated data points for each age class containing $\mathrm{n}$ plots are not independent (cf. Vellend 2001).

\section{Results}

Six and three species were significantly associated with ancient and recent Quercion forests, respectively (Table 1). Interestingly, all species associated with recent forest were bryophytes. In the Alno-Padion forests, nine and five species were associated with ancient and recent forest, respectively (Table 1). Plots of ancient Q uercion forests had a higher contribution of geophytes, while there was a higher number of moss species in recent forest stands (Table 2a). Ancient forests within the A Ino-Padion communities were richer in geophytes and chamaephytes and poorer in therophytes and hemicryptophytes (Table $2 \mathrm{~b}$ ).

The Shannon-Wiener diversity index and the equitability were indifferent for forest age in both forest types (Table 3). Species richness was significantly lower in the youngest Alno-Padion forests, while a more gradual, but only marginally significant, increase in species richness through time is observed in Quercion forests. Furthermore, except for equitability, all the other measures had lower values in the latter forest type compared to the Alno-Padion-forests. The log normal model best fitted the observed patterns of species abundance in all age classes of Alno-Padion

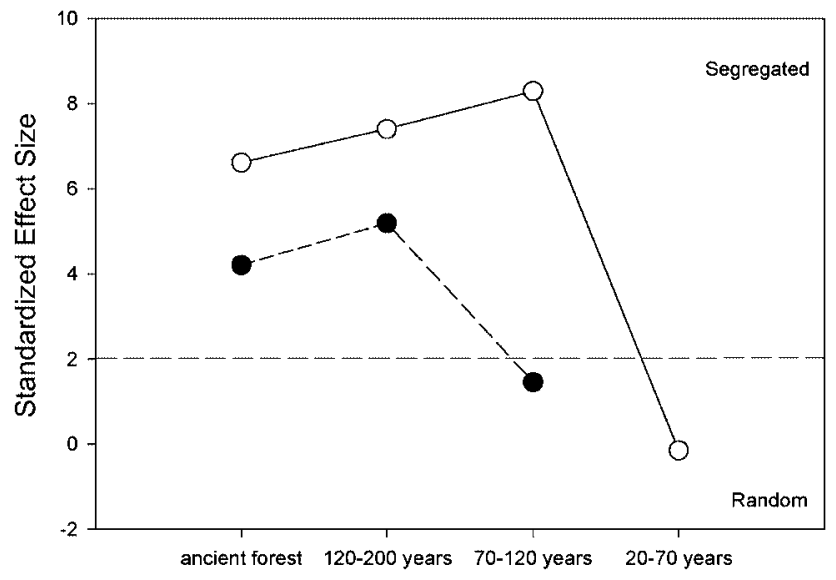

Fig. 1. Species co-occurrence patterns in the different age classes of the Quercion forests (filled dots) and the Alno-Padion forests (empty dots). The standardized C-score of is a measure of the extent to which species co-occur less frequently than expected by chance. Larger $\mathrm{C}$-scores indicate less $\mathrm{co-0C}-$ currence than in randomly assembled communities. The dashed line indicates a standardized effect size of 2.0, which is the approximate 5\% significance level. 
Table 2. Differences in the relative contribution of the life-forms expressed as species and cover values between the forest age classes for the Quercion forests (a) and Alno-Padion forests (b). Median values are given and results of Mann-Whitney ( $f$ ) test and Kruskal-Wallis test $(\$)$ (ns, non significant; $(*), 0.1>p \geq 0.05$; $*, 0.05>p \geq 0.01 ; * *, 0.01>p \geq 0.001)$. Significant differences between age classes are indicated with different letters.

\section{a. Quercion forests}

\begin{tabular}{|c|c|c|c|c|c|c|c|}
\hline & $\begin{array}{l}\text { Ancient forest } \\
N=43\end{array}$ & $\begin{array}{l}\text { Recent forest } \\
N=26\end{array}$ & $p f$ & $\begin{array}{l}\text { Ancient forest } \\
N=43\end{array}$ & $\begin{array}{l}120-200 \text { years } \\
N=15\end{array}$ & $\begin{array}{l}70-120 \text { years } \\
N=10\end{array}$ & $p \$$ \\
\hline \multicolumn{8}{|c|}{ Number of species (\%) } \\
\hline Therophytes & 0 & 0 & ns & 0 & 0 & 0 & ns \\
\hline Geophytes & 5 & 0 & $* * *$ & $5^{\mathrm{a}}$ & $0^{b}$ & $0^{\mathrm{b}}$ & $* *$ \\
\hline Hemicryptophytes & 38 & 33 & ns & 38 & 33 & 30 & ns \\
\hline Chamaephytes & 0 & 0 & $(*)$ & 0 & 0 & 0 & ns \\
\hline Lianes & 0 & 0 & $(*)$ & 0 & 0 & 0 & ns \\
\hline Woody species & 13 & 10 & ns & 13 & 9 & 11 & ns \\
\hline Bryophytes & 33 & 50 & $* *$ & $33^{a}$ & $53^{a b}$ & $50^{b}$ & $*$ \\
\hline \multicolumn{8}{|l|}{ Cover $(\%)$} \\
\hline Therophytes & 0 & 0 & ns & 0 & 0 & 0 & ns \\
\hline Geophytes & 1 & 0 & $* *$ & $1^{\mathrm{a}}$ & $0^{a b}$ & $0^{b}$ & ** \\
\hline Hemicryptophytes & 26 & 19 & ns & 26 & 13 & 26 & ns \\
\hline Chamaephytes & 0 & 0 & $(*)$ & 0 & 0 & 0 & ns \\
\hline Lianes & 0 & 0 & $(*)$ & 0 & 0 & 0 & ns \\
\hline Woody species & 17 & 13 & ns & 17 & 13 & 10 & ns \\
\hline Bryophytes & 7 & 19 & ns & 7 & 10 & 30 & ns \\
\hline
\end{tabular}

\section{b. Alno-Padion forests}

\begin{tabular}{|c|c|c|c|c|c|c|c|c|}
\hline & $\begin{array}{l}\text { Ancient forest } \\
N=63\end{array}$ & $\begin{array}{l}\text { Recent forest } \\
N=64\end{array}$ & $p f$ & $\begin{array}{l}\text { Ancient forest } \\
N=63\end{array}$ & $\begin{array}{l}120-200 \text { years } \\
N=15\end{array}$ & $\begin{array}{l}70-120 \text { years } \\
N=38\end{array}$ & $\begin{array}{l}20-70 \text { years } \\
N=10\end{array}$ & $p \$$ \\
\hline \multicolumn{9}{|c|}{ Number of species (\%) } \\
\hline Therophytes & 8 & 9 & ns & 8 & 10 & 8 & 13 & ns \\
\hline Geophytes & 14 & 12 & ns & 14 & 14 & 11 & 8 & $(*)$ \\
\hline Hemicryptophytes & 46 & 48 & ns & 46 & 50 & 48 & 44 & ns \\
\hline Chamaephytes & 3 & 0 & $*$ & 3 & 0 & 0 & 2 & ns \\
\hline Lianes & 3 & 0 & ns & 3 & 0 & 0 & 2 & ns \\
\hline Woody species & 8 & 9 & ns & 8 & 8 & 9 & 13 & ns \\
\hline Bryophytes & 15 & 15 & ns & 15 & 13 & 15 & 16 & ns \\
\hline \multicolumn{9}{|l|}{ Cover $(\%)$} \\
\hline Therophytes & 2 & 4 & $*$ & 2 & 5 & 4 & 4 & $(*)$ \\
\hline Geophytes & 21 & 8 & * & $21^{\mathrm{a}}$ & $14^{\mathrm{ab}}$ & $8^{a b}$ & $3^{b}$ & * \\
\hline Hemicryptophytes & 30 & 45 & * & 30 & 40 & 46 & 26 & $(*)$ \\
\hline Chamaephytes & 4 & 0 & $* * *$ & $4^{\mathrm{a}}$ & $0^{\mathrm{b}}$ & $0^{\mathrm{b}}$ & $2^{b}$ & $* *$ \\
\hline Lianes & 0.4 & 0 & ns & 0.4 & 0 & 0 & 0 & ns \\
\hline Woody species & 8 & 10 & ns & 8 & 6 & 14 & 12 & ns \\
\hline Bryophytes & 8 & 7 & ns & 6 & 7 & 8 & 6 & ns \\
\hline
\end{tabular}

Table 3. Differences in average number of species, total cover, Shannon-W iener diversity index and equitability between the age classes for the two forest types. Median values are given and results of Mann-Whitney $(f)$ test and Kruskal-Wallis test ( $\$$ ) (ns, non significant; $(*), 0.1>p \geq 0.05 ; *, 0.05>p \geq 0.01 ; * *$, $0.01>p \geq 0.001$ ). Significant differences between age classes are indicated with different letters.

\begin{tabular}{|c|c|c|c|c|c|c|c|c|}
\hline & Ancient forest & Recent forest & $p f$ & Ancient forest & $120-200$ years & $70-120$ years & $20-70$ years & $p \$$ \\
\hline $\begin{array}{l}\text { Quercion forests } \\
\text { Total cover (\%) } \\
\text { Number of species } \\
\text { Diversity } \\
\text { Equitability }\end{array}$ & $\begin{array}{l}N=43 \\
51 \\
13 \\
1.83 \\
0.71\end{array}$ & $\begin{array}{l}N=26 \\
49.5 \\
8.5 \\
1.71 \\
0.70\end{array}$ & $\begin{array}{l}\text { ns } \\
* \\
\text { ns } \\
\text { ns }\end{array}$ & $\begin{array}{l}N=43 \\
51 \\
13 \\
1.83 \\
0.71\end{array}$ & $\begin{array}{l}N=15 \\
67 \\
11 \\
1.76 \\
0.63\end{array}$ & $\begin{array}{l}\mathrm{N}=10 \\
16.5 \\
8 \\
1.81 \\
0.84\end{array}$ & $N=0$ & $\begin{array}{l}\text { ns } \\
(*) \\
\text { ns } \\
\text { ns }\end{array}$ \\
\hline $\begin{array}{l}\text { Alno-Padion forests } \\
\text { Total cover }(\%) \\
\text { Number of species } \\
\text { Diversity } \\
\text { Equitability }\end{array}$ & $\begin{array}{l}N=63 \\
130 \\
26 \\
2.22 \\
0.68\end{array}$ & $\begin{array}{l}N=64 \\
118 \\
26 \\
2.20 \\
0.69\end{array}$ & $\begin{array}{l}* \\
\text { ns } \\
\text { ns } \\
\text { ns }\end{array}$ & $\begin{array}{l}N=63 \\
130^{\mathrm{a}} \\
26^{\mathrm{a}} \\
2.22 \\
0.68\end{array}$ & $\begin{array}{l}N=15 \\
116^{\mathrm{a}} \\
28^{\mathrm{a}} \\
2.35 \\
0.71\end{array}$ & $\begin{array}{l}\mathrm{N}=38 \\
122^{\mathrm{a}} \\
27^{\mathrm{a}} \\
2.24 \\
0.68\end{array}$ & $\begin{array}{l}N=10 \\
92^{b} \\
16^{b} \\
1.88 \\
0.67\end{array}$ & $\begin{array}{l}* \\
* * \\
\mathrm{~ns} \\
\mathrm{nS}\end{array}$ \\
\hline
\end{tabular}


forests (Table 4). By contrast, the log normal model was less frequently the best model in the Quercion forests. The geometric model was more important in younger forests of this type.

We found similar patterns of co-occurrence in both forest types (Fig. 1). Co-occurrence patterns in the youngest $Q$ uercion and Alno-Padion forests did not differ significantly from random and there was less cooccurrence than expected (i.e. segregation) in the older forests of both types.

O nly for Q uercion forests, there was a tendency of decreasing dissimilarity with increasing forest age (Table 5). In this forest type, plots in ancient forests were on average more similar than in recent forests.

\section{Discussion}

\section{Changes in species composition and life-forms}

The age-sensitive species in this study match well with those listed in earlier publications (e.g. H onnay et al. 1998, H ermy et al. 1999), and make up a considerable

Table 4. Frequencies (\%) of the best fitting rank abundance models in the different age classes and forest types. No fit means that the observed rank abundance curve differed significantly from all the tested models or that too few abundance classes were present to perform a test.

\begin{tabular}{llllc}
\hline & $\begin{array}{l}\text { Ancient } \\
\text { forest }\end{array}$ & $\begin{array}{l}120-200 \\
\text { years }\end{array}$ & $\begin{array}{l}70-120 \\
\text { years }\end{array}$ & $\begin{array}{l}20-70 \\
\text { years }\end{array}$ \\
\hline $\begin{array}{l}\text { Quercion forests } \\
\text { Geometric }\end{array}$ & $\mathrm{N}=43$ & $\mathrm{~N}=15$ & $\mathrm{~N}=10$ & $\mathrm{~N}=0$ \\
Log series & 19 & 20 & 50 & \\
Log normal & 19 & 13 & 10 & \\
Broken stick & 41 & 27 & 10 & \\
No fit & 5 & 0 & 0 & \\
& 16 & 40 & 30 & \\
Alno-Padion forests & $\mathrm{N}=63$ & $\mathrm{~N}=15$ & $\mathrm{~N}=38$ & $\mathrm{~N}=10$ \\
Geometric & 3 & 7 & 5 & 0 \\
Log series & 3 & 0 & 8 & 0 \\
Log normal & 80 & 86 & 82 & 100 \\
Broken stick & 0 & 0 & 0 & 0 \\
No fit & 14 & 7 & 5 & 0 \\
\hline
\end{tabular}

fraction of the total forest flora (respectively $36 \%$ and $27 \%$ of the tested species in the Q uercion and A Ino-Padion forests). Persistent differences between ancient and recent forests in life-form spectra in general and in the number and abundance of geophytes in particular have been found before (e.g. Graae \& Sunde 2000). The low number and abundance of forest geophytes in recent forests is likely due to the fact that they often produce few and badly dispersed seeds (e.g. Bierzychudek 1982) which reduces their chances for early colonization. In Q uercion forests, it is mainly the relative proportion of the life-forms in the species number that changes through time (Table 2a), while in AlnoPadion forests it are mainly the relative cover values that are still changing at late successional stages (Table 2b). Differences in productivity between Q uercion and Alno-Padion forests may explain these patterns. After agricultural abandonment and planting of trees, soil $\mathrm{pH}$ decreases quickly and a thick mor or moder litter layer develops in the well-drained Q uercion forests (e.g. Bossuyt et al. 1999b, Richter et al. 1999). These site conditions, together with intense below-ground competition with the shallow roots of canopy species (cf. Coomes \& Grubb 2000), make that the herb layer is relatively sparse (median total cover is $50 \%$; Table 3). The more mesic soils of Alno-Padion communities on the other hand are better buffered, and most often a mull humus type is perpetuated through rapid litter decomposition (e.g. M uys 1993). H ence, a dense herb layer can develop (median total cover exceeds $120 \%$ ). It can thus be assumed that herb layer dynamics in the latter community follow a 'zero-sum game' (H ubbell 2001). This means that increases in the abundance of one herb layer species must be accompanied by a matching decrease in the abundance of other species. Such a tight coupling is less likely in the less productive Q uercion forests.

\section{Changes in community structure}

The qualitative differences between ancient and recent forests are (at least) partially reflected by the community structure of the forests. Classical succession theo-

Table 5. M ean dissimilarity - measured as the Euclidean distance between each pair of plots - for the age classes of the two forest types. The significance of the Monte Carlo ANOVA test is given (ns, non significant; $*, 0.05>p \geq 0.01 ; * *, 0.01>p \geq 0.001$ ) and significant differences between age classes are indicated with different letters.

\begin{tabular}{|c|c|c|c|c|c|c|c|c|}
\hline & Ancient forest & Recent forest & $p f$ & Ancient forest & $120-200$ years & $70-120$ years & $20-70$ years & $p \$$ \\
\hline $\begin{array}{l}\text { Quercion forests } \\
\text { Dissimilarity }\end{array}$ & $\begin{array}{l}N=903 \\
48.2\end{array}$ & $\begin{array}{l}N=325 \\
52.8\end{array}$ & $*$ & $\begin{array}{l}N=903 \\
27.7^{\mathrm{a}}\end{array}$ & $\begin{array}{l}N=105 \\
34.9^{b}\end{array}$ & $\begin{array}{l}N=45 \\
34.7^{b}\end{array}$ & $N=0$ & $* *$ \\
\hline $\begin{array}{l}\text { Alno-padion forests } \\
\text { Dissimilarity }\end{array}$ & $\begin{array}{l}N=1953 \\
70.9\end{array}$ & $\begin{array}{l}N=2016 \\
69.8\end{array}$ & ns & $\begin{array}{l}N=1953 \\
70.9\end{array}$ & $\begin{array}{l}N=105 \\
67.0\end{array}$ & $\begin{array}{l}N=703 \\
70.8\end{array}$ & $\begin{array}{l}N=45 \\
67.8\end{array}$ & ns \\
\hline
\end{tabular}


ry (see $O$ dum 1969, Drury \& N isbet 1973, M cCook 1994) predicts higher species diversity, higher evenness and better organised diversity patterns during succession. These predictions are, how ever, not entirely valid for the forest types under study. At the plot level, the species number gradually increases in Quercion forests, while it remains constant after 70 years in Alno-Padion forests. Species saturation is indeed likely to occur in the late successional Alno-Padion forest plots (i.e. 70 years and older) that are assumed to obey 'zero-sum dynamics' (cf. above). By contrast, species accumulation can continue in the Quercion forest plots and in the very young Alno-Padion forest plots which both have a less dense herb layer (cf. Table 3).

In contrast to predictions of successional theory, no differences in diversity and equitability were found between ancient and recent forests in any of the types. These results were only partly confirmed by examination of the rank abundance curves. In the relatively diverse Alno-Padion forests, the widely applicable log normal species abundance distribution best fitted the data independently of forest age. $\mathrm{H}$ owever, there was a tendency towards more geometric species abundance distributions in younger $\mathrm{Q}$ uercion forests, suggesting less evenness. Such a pattern has been observed before by other authors studying (early) forest succession (e.g. Bazzaz 1975, Grant \& Loneragan 2003).

Using exactly the same randomization algorithm, Gotelli \& M cCabe (2002) found less co-occurrence than expected by chance for plants as well as for several other taxonomic groups. H ow ever, besides competitive interactions, several other mechanisms could also produce the observed patterns of species segregation (Gotelli \& M cCabe 2002, Sanders et al. 2003) and hence, we suggest that the most important message here is the increasing degree of non-randomness of species co-occurrence in communities recovering from past-agricultural use rather than the increasing segregation of species. These patterns can be explained by the strong dispersal limitation experienced by many forest species (e.g. M atlack 1994, Brunet \& von Oheimb 1998, Bossuyt et al. 1999a, Verheyen et al. 2003). Due to dispersal limitation, the species composition in the youngest forests is largely determined by chance (e.g. the accidental availability of nearby seed sources). As succession proceeds, more and more slowly dispersing species from the regional species pool are also able to colonize the local successional communities and hence, local environmental factors and species interactions will become more important in structuring the local community composition (cf. Christensen \& Peet 1984). We suspect that the slower recovery of community structure in the Q uercion forests is due to fact that not only dispersal limitation, but also establishment limitation is important in these communities.
Especially the thick litter layer may be crucial in this respect. The lower overall degree in community structure in the Q uercion forests is believed to be caused by the less tight coupling of species occurrence and abundance patterns as discussed above.

The mean dissimilarity represents the expected difference in species composition between a randomly chosen pair of plots (Vellend 2001, Ricotta et al. 2002). The lower difference in the ancient Quercion forests could be interpreted as successional convergence. The decreasing importance of dispersal limitation could also serve as an explanation here. Based on the previous results, we expected dissimilarity in the youngest forests to be higher in Alno-Padion forests, but in this community no indications for convergence or divergence were found. M aybe convergence would have been detected when even younger forests would have been sampled. No unequivocal patterns emerge from other studies either (e.g. Persson 1980, Zobel et al. 1993, Dzwonko \& Gawronski 1994). However, since various indices to estimate beta-diversity and species turnover have been used it is difficult to compare the results of different studies (Vellend 2001). Furthermore, Leps \& Rejmanek (1991) listed possible confounding factors that may influence the apparent or real convergence or divergence of successional seres.

\section{Conclusions}

We can conclude that, even after a century, the composition and structure of herb layer communities in forests recovering from past-agricultural use are still different from those in ancient forests. Compositional differences relate both to individual species and to lifeform spectra. Few changes in the community structure of productive A Ino-Padion forests were observed after 70 years. O nly in the youngest Alno-Padion forests (i.e. $<70$ years) species numbers and total cover of the herb layer were lower and co-occurrence patterns did not differ from random. In general, community recovery appeared to be slower in unproductive Quercion forests. Species numbers, species abundance distributions, species co-occurrence patterns and plot dissimilarity still changed after 120 years. The persistent differences in both communities can be explained by the strong dispersal limitation of many of the involved species, but in the Quercion forests recovery is probably also severely hampered by establishment limitation.

Acknowlegdements. The authors want to thank $\mathrm{H}$ ans Jacquemyn and two anonymous referees for their helpful comments on an earlier version of this manuscript. KV, BB and $\mathrm{OH}$ have a postdoctoral fellowship from the Flemish Fund for Scientific R esearch (F.W.O.). 


\section{References}

Bazzaz FA (1975) Plant species diversity in old field successional ecosystems in Southern Illinois. Ecology 56: 485- 488.

Bierzychudek, P (1982) Life histories and demography of shade-tolerant temperate forest herbs: a review. N ew Phytologist 90: 757-776.

Begon M , H arper JL, Townsend CR (1996) Ecology. Blackwell Science, Oxford, UK.

Bossuyt B, Hermy M, Deckers S (1999a) M igration of herbaceous plant species across ancient-recent forest ecotones in central Belgium. Journal of Ecology 87: 628-638.

Bossuyt B, Deckers S, Hermy M (1999b) A field methodology for assessing man-made disturbance in forest soils developed in loess. Soil Use and M anagement 15: 14-20.

Brunet J (1993) Environmental and historical factors limiting the distribution of rare forest grasses in south Sweden. Forest Ecology and $M$ anagement 61: 236-275.

Brunet J, von O heimb G (1998) M igration of vascular plants to secondary woodlands in southern Sweden. Journal of Ecology 86: 429-438.

Butaye J, Jacquemyn H, H ermy M (2001) Differential colonization causing non-random forest plant community structure in a fragmented agricultural landscape. Ecography $24: 369-380$.

Christensen N L, Peet RK (1984) Convergence during forest succession. Journal of Ecology 72: 25-36.

Coomes D A, G rubb, PJ (2000) Impacts of root competition in forests and woodlands: a theoretical framew ork and review of experiments. Ecological M onographs 70: 171-207.

De Langhe JE, Delvosalle L, Duvigneaud L, Lambinon J, Vanden Berghen C (1983) Flora van België, het Groothertogdom Luxemburg, Noord-Frankrijk en de aangrenzende gebieden. $\mathrm{N}$ ationale Plantentuin België, $\mathrm{M}$ eise.

Drury WH, N isbet ICT (1973) Succession. The Arnold Arboretum J ournal 54: 331-368.

Dzwonko Z (2001) Effect of proximity to ancient deciduous woodland on restoration of the field layer vegetation in a pine plantation. Ecography 24: 198-204.

Dzwonko Z, Loster S (1990) Vegetation differentiation and secondary succession on a limestone hill in southern Poland. J ournal of Vegetation Science 1: 615-622.

Dzwonko Z, Loster S (1992) Species richness and seed dispersal to secondary woods in southern Poland. Journal of Biogeography 19: 195-204.

Dzwonko Z, Gawronski S (1994) The role of woodland fragments, soil type, and dominant species in secondary succession on the Western Carpatian foothills. Vegetatio 11: $149-160$.

Gotelli N J, Entsminger GL (2002) ECOSIM 7.0. N ull M odels Software for Ecology. A cquired Intelligence, Inc. \& Kesey Bear, Burlington, Vermont.

Gotelli NJ, M cCabe DJ (2002) Species co-occurrence: a meta-analysis of J. M. Diamond's assembly rules model. Ecology 83: 2091- 2096.

Graae JB, Sunde, PB (2000) The impact of forest continuity and management on forest floor vegetation evaluated by species traits. Ecography 23: 720-731.

Grant CD, Loneragan WA (2003) Using dominance-diversity curves to assess completion criteria after bauxite min- ing rehabilitation in Western Australia. Restoration Ecology 11: 103-109.

Grashof-Bokdam C (1997) Forest species in an agricultural landscape in the $\mathrm{N}$ etherlands: effects of habitat fragmentation. Journal of Vegetation Science 8: 21-28.

Grime JP (1977) Evidence for the existence of three primary strategies in plants and its relevance to ecological and evolutionary theory. American N aturalist 111: 1169-1194.

Halpern CB, Frenzen PM, M eans JE, Franklin JF (1990) Plant succession in areas of scorched and blow-down forest after the 1980 eruption of M ount St. H elens, Washington. J ournal of Vegetation Science 1: 181- 194.

H ermy M (1988) Correlation betw een forest layers in mixed deciduous forests in Flanders (Beglium). In: During $\mathrm{HJ}$, Werger M JA, Willems JH (eds) Diversity and pattern in plant communities. SPB Academic Publishing, The Hague, pp 77-85.

Hermy M (1992) O ak-Birch woodlands (Quercion RoboriPetraeae) of the A tlantic domain in Belgium. Belgian J ournal of Botany 125: 114-136.

Hermy M , Stieperaere H (1981) An indirect gradient analysis of the ecological relationships between ancient and recent riverine woodlands to the south of Bruges. Vegetatio 44: 46- 49.

H ermy M, H onnay O, Firbank L, G rashof-Bokdam C, Lawesson JE (1999) An ecological comparison between ancient and other forest plant species of Europe, and the implications for conservation. Biological Conservation 91: 9-22.

Hill MO (1979) TWIN SPAN - a FORTRAN program for arranging multivariate data in an ordered tw wy table by classification of the individuals and the attributes. Cornell University, Ithaca, N ew York.

Honnay O, Degroote B, Hermy M (1998) Ancient-forest plant species in Western Belgium: a species list and possible ecological mechanisms. Belgian Journal of Botany 130: 139-154.

Honnay O, Hermy M, Coppin P (1999) Impact of habitat quality on forest plant species colonization. Forest Ecology and $M$ anagement 115: 157-170.

Hubbell SP (2001) A unified neutral theory for biodiversity and biogeography. Princeton University Press, Princeton.

Kosala KR, Gross KL (1999) Resource competition and suppression of plants colonizing early successional old fields. O ecologia 118: 69-75.

Leps J, Rejmanek M (1991) Convergence or divergence. What should we expect from vegetation succession? O ikos 62: 261-264.

Londo G (1976) The decimal scale for relevés of permanent quadrats. Vegetatio 33: 61-64.

$M$ agurran AE (1988) Ecological diversity and its measurement. Croom H elm, Sydney.

M ardagant WD (1973) Beknopte blad- en levermossenflora van $\mathrm{N}$ ederland. Afl. 1. Algemene tabel en levermossen. KN N V, Hoogwoud.

M ardagant WD, During H (1973) Beknopte blad- en levermossenflora van $\mathrm{N}$ ederland. Afl. 2. Algemene tabellen en bladmossen, Afl. 3. Geslachtstabellen bladmossen. KN N V, Hoogwoud.

M atlack G (1994) Plant species migration in a mixed-history forest landscape in eastern $\mathrm{N}$ orth America. Ecology 75: 1491-1502. 
M cCook LJ (1994) Understanding ecological community succession: causal models and theories: a review. Vegetatio 110: 115-147.

M uys B (1993) A synecological evaluation of the earthworm activity and litter decomposition in Flemish forests in the context of sustainable forest management. Ph.D. thesis, University of Ghent, G hent.

O dum EP (1969) The strategy of ecosystem development. Science 164: 262-270.

Persson S (1980) Succession in a South Swedish deciduous wood: a numerical approach. Vegetatio 43: 103-122.

Peterken GF (1974) A method of assessing woodland flora for conservation using indicator species. Biological Conservation 6: 239-245.

Pisces Conservation Ltd (2002) Species Diversity \& Richness III. Version 3.0. Pisces Conservation Ltd, Lymington, UK.

Raunkiaer C (1934) The life forms of plants and statistical plant geography. Clarendon, 0 xford.

Richter DD, M arkewitz D, Trumbore SE, Wells CG (1999) Rapid accumulation and turnover of soil carbon in a reestablishing forest. N ature 400: $56-58$.

Ricotta C, Carranza M L, Avena G (2002) Computing $\beta$-diversity from species-area curves. Basic and Applied Ecology 3: 15-18.

Sanders N J, Gotelli N J, H eller N E, Gorden DM (2003) Community disassembly by an invasive species. Proceedings of the $N$ ational A cademy of Sciences 100: 2474-2477.

Siegel S, Castellan NJ (1988) N on-parametric statistics for the behavioral sciences. M cG raw-Hill, N ew York.

Stone L, Roberts A (1990) Competitive-exclusion, or species aggregation. An aid in deciding. O ecologia 85: 74-79.
Tack G, van den Brempt P, H ermy M (1993) Forests of Flanders. An ecological history. Davidsfonds, Leuven.

Tilman D (1987) Secondary succession and the pattern of plant dominance along experimental nitrogen gradients. Ecological M onographs 57: 189-214.

Tilman D (1988) D ynamics and structure of plant communities. Princeton University Press, Princeton.

Vellend M (2001) Do commonly used indices of $\beta$-diversity measure species turnover? Journal of Vegetation Science 12: 545-552.

Verheyen K, Hermy M (2001) The relative importance of dispersal limitation of vascular plants in seconary forest succession in M uizen Forest, Belgium. Journal of Ecology 89: 829-840.

Verheyen K, Bossuyt B, Hermy M , Tack G (1999) The land use history (1278-1990) of a mixed hardwood forest in Western Belgium and its relationship with chemical soil characteristics. Journal of Biogeography 26: 1115-1128.

Verheyen $\mathrm{K}, \mathrm{H}$ onnay $\mathrm{O}$, M otzkin $\mathrm{G}, \mathrm{H}$ ermy $\mathrm{M}$, Foster DR (2003) Response of forest plant species to land-use change: a life-history trait-based approach. Journal of Ecology 91: 563-577.

Westhoff V, van der M aarel E (1978) The Braun-Blanquet approach. In: Whittaker RH (ed) Classification of plant communities. Junk, Den H aag, pp 287- 299.

Wulf M (1997) Plant species as indicators of ancient woodland in north-w estern Germany. J ournal of Vegetation Science 8: 635-642.

Zobel K, Z obel M, Peet RK (1993) Change in pattern diversity during secondary succession in Estonian forests. Journal of Vegetation Science 4: 489-498. 